\title{
Ethnoecology of Zanthoxylum acanthopodium by local communities around Lake Toba, North Sumatra, Indonesia
}

\author{
YATI NURLAENI ${ }^{1,2, \bullet}$, JOHAN ISKANDAR $^{1,3,4, v \vee}$, DECKY INDRAWAN JUNAEDI $^{2}$ \\ ${ }^{1}$ Environmental Science Graduate Program, Graduate School, Universitas Padjadjaran. Jl. Sekeloa Selatan I, Bandung 40134, West Java, Indonesia. \\ Tel.: +62-22-2508871, Fax.: +62-22-2504982, ‘email: yatinurlaeni007@gmail.com, •"johan.iskandar@ unpad.ac.id, deqee82@gmail.com \\ ${ }^{2}$ Cibodas Botanical Garden, Research Center for Plant Conservation and Botanical Garden, Indonesian Institute of Sciences. Jl. Kebun Raya Cibodas, \\ Sindanglaya, Cipanas, Cianjur 43253, West Java, Indonesia \\ ${ }^{3}$ Department of Biology, Faculty of Mathematics and Natural Sciences, Universitas Padjajaran. Jl. Raya Bandung-Sumedang Km 21, Jatinangor, \\ Sumedang 45363, West Java, Indonesia \\ ${ }^{4}$ Center for Environment and Sustainabilty Science (CESS), Universitas Padjadjaran. Jl. Sekeloa Selatan 1, Bandung 40134, West Java, Indonesia
}

Manuscript received: 2 January 2021. Revision accepted: 19 March 2021.

\begin{abstract}
Nurlaeni Y, Iskandar J, Junaedi DI. 2021. Ethnoecology of Zanthoxylum acanthopodium by local communities around Lake Toba, North Sumatra, Indonesia. Biodiversitas 22: 1806-1818. Zanthoxylum acanthopodium DC., locally known as andaliman, is a typical spice of traditional cuisine of communities living around Lake Toba, North Sumatra, Indonesia. Despite the extensive uses, the ethnoecological study on this plant is relatively scarce. This study aims to conduct ethnoecological studies of the management and cultivation of andaliman plants based on Traditional Ecological Knowledge of local communities of Salaon Dolok Village, a village nearby Lake Toba which has close relationship and intensively cultivated/utilized andaliman in their daily life. This study applied qualitative methods using the combination of direct observation and interviews with 46 selected respondents using snowball sampling. The results of this study showed that the cultivation of andaliman in Salaon Dolok Village was carried out using traditional ways with simple farming practices. These traditional farming models relied on manual farming practices in all farming aspects. The community has local knowledge related to the management of reliable agricultural systems from generation to generation. Andaliman cultivation in Salaon Dolok Village does not need maintenance costs for fertilizers and pesticides. In general, andaliman planting is mostly done in the forest. In general, the people of this village only recognize two kinds of andaliman cultivars, namely Andaliman 'Simanuk' and Andaliman 'Sihorbo'. The planting is usually carried out during the rainy season to reduce the mortality rate of the planted seedlings. The activity of seedling preparation is carried out in two simple ways. First, most farmers were collected andaliman seeds that grow wild around the existing andaliman plants. The second method is by collecting the seedling that grows from the burning land with some remains of old andaliman plants collected at the edge of the land. Sustainable agriculture should minimize the external input from outside of the agro-ecosystem. Low External Input Sustainable Agriculture (LEISA) emphasizes the efficient use of existing production factors to create sustainable agriculture, including for andaliman agriculture system.
\end{abstract}

Keywords: Andaliman, agro-ecosystem, ethnoecology, local communities of Salaon Dolok, Lake Toba, snowball sampling

\section{INTRODUCTION}

Andaliman (Zanthoxylum acanthopodium DC.) Is a member of the genus Zanthoxylum, Rutaceae family. Andaliman is a wild plant that has a shrub in shape and has a plant height of up to $6 \mathrm{~m}$. The trunk is woody with a diameter of $5-10 \mathrm{~cm}$, and has thorns. Leaf shape is an oddpinnate compound leaf, opposite, 3-7 leaflets, green leaves, oval-oval to curved leaflets, both surfaces are visible, oil glands are striking, leaf edges are flat or serrated (Hartley 1966). Andaliman flowers are small, pale yellow, hermaphrodite, 5-7 free sepals, 5-6 stamens, reddish anther, sticky pollen, 3-4 pistils sometimes 5 pistils, are apocarpous (Siregar et al. 2019). The young andaliman fruits are green, round and small, smaller than a pepper, smell like lemon, have a distinctive sharp taste, and can stimulate saliva production. Ripe fruit is dark red to brownish red and turns black quickly after picking it. The seeds are inside the fruit and hard. The seeds are round in shape, the seeds are white when they are young and black when they are old (Simbolon et al. 2018; Anggraeni 2019).
Andaliman lushly grows in subtropical climate in Himalayan mountain, and spread to eastern Pakistan, northern India, Nepal, Bhutan, China, Japan, Bangladesh, Laos, Myanmar, Thailand, Vietnam, Malayan Peninsula, and North Sumatra in Indonesia (Hartley 1966). In Indonesia, andaliman naturally distributed in northern part of Sumatra. In North Sumatra, andaliman is distributed in the areas adjacent to Lake Toba, including in the districts of Simalungun, Dairi, Humbang Hasudutan, Samosir, Toba Samosir, Karo, North Tapanuli and South Tapanuli (Harsono et al. 2016; Suriani et al. 2019). Andaliman usually occurs in areas with an altitude of more than 1300 $\mathrm{m}$ above sea level with a temperature of $15-18{ }^{\circ} \mathrm{C}$. This plant is one type of spice that has not been widely known by the people of Indonesia (Hartley 1966; Hasairin 2014). In Indonesia, people around the Lake Toba area recognize andaliman as a spice for cooking with a distinctive, mild, bitter taste. The part of the andaliman plant that consumed is the fruit and its seeds. Generally, people use andaliman as a spice in various types of fresh dishes. This species is a typical spice in traditional cuisine around Lake Toba and 
has many important functions for Batak communities who live around the lake. Apart from being used as spices in traditional Batak cooking (Hasairin 1994), other potential uses of andaliman include medicinal purposes that function as antioxidants (Kristanty and Suriawati 2014; Karnady 2015; Wijaya et al. 2019), anti-fungal (Devi et al. 2015), antibacterial (Parhusip et al. 2010; Sitanggang et al. 2019; Susanti et al. 2020), antidiabetic (Harahap et al. 2018; Worotikan et al. 2018) and anticancer (Tjahjandarie et al. 2019; Satria 2020; Sibero et al. 2020).

In Batak communities, the consumption of andaliman usually increases during religious events or traditional ceremonial celebrations. The selling price of andaliman is relatively high at the end of the year when the Batak people celebrate Christmas and New Year. At this time, andaliman prices may reach 200,000 IDR per kg (Simorangkir 2019). The high demand of andaliman either for local needs in North Sumatra or outside North Sumatra has triggered the increasing demand for andaliman in general. Besides, since Lake Toba is a major tourism destination in North Sumatra, andaliman is required to support culinary tourism (Lestari and Levina 2018; Nugraha and Sumardi 2019) as well as to be exported abroad.

While there is extensive use of andaliman in Batak communities, its existence in nature is threatened due to various factors, such as decreasing land area, widespread conversion of agricultural land into other functions, low seed germination capacities, undiscovered cultivation techniques, and specific natural distribution habitat in the area around Lake Toba. The local communities around Lake Toba had depth knowledge about andaliman in the past. However, such knowledge is not inherited from current generations, resulting in an erosion of the local knowledge of andaliman.

One local community with close relationships and intensively cultivated and utilized andaliman in their daily lives is located in Salaon Dolok Village, Ronggur Nihuta Sub-district, Samosir District. Most of Salaon Dolok Village area are agricultural lands and forested areas in hilly and sloping lands. Salaon Dolok Village is famous as an andaliman producer in Samosir District because andaliman from this village has stronger taste and unique aroma that is popular among many people. The local knowledge and culture of Salaon Dolok Village can be connected with modern science to develop environmentally friendly and sustainable use of andaliman. Studies that investigate the interaction between the people of Salaon Dolok Village and their environment regarding the cultivation of andaliman is essential to reveal local communities knowledge system of andaliman in this area. Salaon Dolok Village people have a variety of different local wisdom in farmland management and cultivation of andaliman.

Several studies on andaliman have been carried out including germination and breaking of seed dormancy (Siregar 2013); the content of chemical compounds (Wijaya et al. 2019; Napitupulu et al. 2020; Arsita et al. 2019); genetic diversity (Raja and Hartana 2017; Simbolon et al. 2018; Siregar et al. 2019); essential oils Wijaya et al. 2019; Sinaga and Prasetyo 2020); immune system (Purba and Sinaga 2017; Faradillah et al. 2020); antiaging and anti-acne (Hanum Ismanelly and Laila 2018); distribution pattern (Suriani et al. 2019; Siahaan et al. 2019); analysis of farming and marketing (Simbolon and Panjaitan 2020); and ecology and conservation (Harsono et al. 2016; Nurlaeni and Junaedi 2018; Junaedi and Nurlaeni 2019). However, study on ethnoecology or Traditional Ecological Knowledge (TEK) of the local community on cultivation of andaliman plant has been rarely undertaken. This study aims to conduct the ethnoecological of the management and cultivation of andaliman plants based on TEK of local communities in Salaon Dolok Village. The local knowledge of management and cultivation of andaliman may contribute to the development of andaliman cultivation best-practices that will support farmers economic growth due to the commercialization of andaliman.

\section{MATERIALS AND METHODS}

\section{Study area and period}

This study was conducted in Salaon Dolok Village, Ronggur Nihuta, Samosir District, North Sumatra (Figure 1). The area is located at $1500 \mathrm{~m}$ above sea level with maximum average temperature is $31.53^{\circ} \mathrm{C}$ and the minimum average temperature is $21.72^{\circ} \mathrm{C}$. The dry season usually occurs from June to September, the rainy season usually occurs from November to March, and between these two seasons there is a transition season (BPS, 2019). Salaon Dolok Village has 243 house-holds in 2020 (Profile of Salaon Dolok 2020). For preliminary data of andaliman location, this study uses the following types of data: primary, interview; and secondary data from literature. Preliminary research was carried out in April 2018 and continued from August to December 2020.

\section{Data collection}

This study used qualitative method by utilizing ethnoecological approach with emphasis on the changes in the process of andaliman management systems in the field (Newing 2010; Albuquerque et al. 2014). Field data were collected by observations and semi-structured deepinterviews. The observation method was used to observe general ecological conditions of the agroecosystem types. Semi-structured interviews (deep interviews) were carried out by involving 46 informants who were considered as competent and knowledgeable persons with agricultural management systems in Salaon Dolok Village. The informants were chosen purposively using snowball sampling in accordance with their respective expertise, including farmers who planted andaliman. The snowball sampling accounted for the diversity (triangulation) based on existing categorization. The informants in this study included the Head of the Plantation Division of the Samosir District Agriculture Services, one plantation officer of the Samosir District Agriculture Service, the head of Salaon Dolok village, a village official of Salaon Dolok, three local hamlet leaders, one agricultural extension officer (Penyuluh Pertanian Lapangan/PPL), two village elders, 
three male farmers and two female farmers who were more than 60 years old, three successful andaliman farmers, ten andaliman farmers, two members of andaliman farmer groups, two traders in the village, two traders in the city, two Bataknese food sellers and ten residents of Salaon Dolok village.

\section{Data analysis}

Data analysis was carried out by conducting crosschecking, summarizing and synthesizing from different sources in order to build up a narrative account (Newing 2010). Cross-checking is conducted to validate the data collected from some implemented data collection techniques, including observation, semi-structured interviews, participatory observations, and secondary data. The validated data then summarized, synthesized, and elaborated into a descriptive narrative containing changes in andaliman traditional agricultural management, including which local andaliman cultivars are still traditionally planted today, how farmers carried out andaliman management and the cultivation that related to andaliman agricultural management.

\section{RESULTS AND DISCUSSION}

\section{Cultivation systems of andaliman}

Salaon Dolok Village consists of three hamlets, namely Dusun I Martabe, Dusun II Merdeka, and Dusun III Dame. The residents of Dusun II who lived in the Huta Siponggol Tanduk and Partungkuoan have been farmers for more than 30 years. The community has local knowledge, cultural values and wisdom are related to the management of reliable agricultural systems from generation to generation. This ability is considered as useful knowledge to cope with agricultural problems.
The andaliman farming system in Salaon Dolok Village is a traditional farming system. Andaliman has been cultivated in Salaon Dolok Village from generation to generation by the local communities in Samosir Protection Forest. Andaliman was planted in the Samosir Protected Forest area and located $4 \mathrm{~km}$ away from residential areas. Andaliman grows in the wild without maintenances, such as the use of fertilizers and pesticides. Generally, farmers check their Andaliman in the forest only once a week. All the cultivation systems applied by farmers (consisting of seeding, planting, maintenance, to harvesting) are done manually and do not depend on sophisticated production facilities and tools.

Aside from common method of Andaliman farming in farmland, local communities also cultivate andaliman as part of agroforestry system that planted under pines trees in Samosir Protected Forest that managed by Unit Pelaksana Teknis Kesatuan Pengelolaan Hutan (KPH) Wilayah XIII Dolok Sanggul (Perhutani). KPH Perhutani collaborates with village communities for these agroforestry practices so that it creates opportunities for the community to manage the land by planting cultivated plants under the shade of pine trees. Limited land availability, population growth and economic needs are some of the problems that are faced by the community. These problems have prompted the community to apply certain techniques in land management and plant use forms. Management and utilization techniques are local knowledge that is owned by the community. Local communities can manage the land under the shade of pine in the Samosir Protected Forests on the condition that these local communities must maintain and be responsible for the safety of the pine trees and manage the land without damaging the forest ecosystem in Samosir Protected Forests (Figure 2.A). KPH Perhutani does not ask for any payment from the management activities carried out by the community in Samosir Protected Forests.

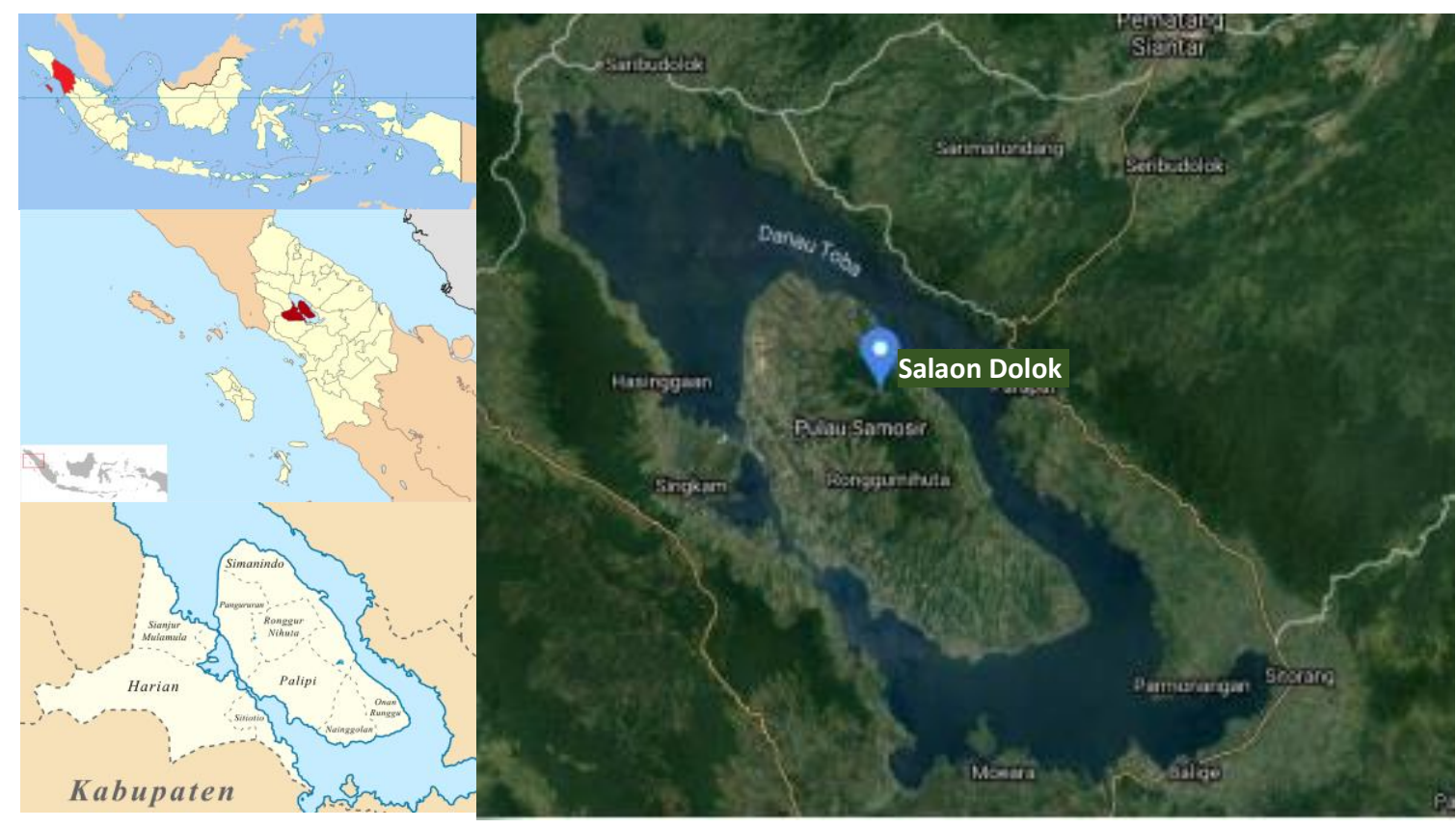

Figure 1. Map of the study location in Salaon Dolok Village, Ronggur Nihuta, Samosir District, North Sumatra, Indonesia 
Table 1. Morphological characters of two andaliman cultivars: Simanuk and Sihorbo in Salaon Dolok Village, North Sumatra, Indonesia (Simbolon et al. 2018)

\begin{tabular}{|c|c|c|}
\hline \multirow{2}{*}{ Parameter } & \multicolumn{2}{|c|}{ Morphological character } \\
\hline & Simanuk & Sihorbo \\
\hline Plant height (m) & $2.6-3.3$ & $2.2-4.9$ \\
\hline $\begin{array}{l}\text { Trunk circumference } \\
(\mathrm{cm})\end{array}$ & $16-29$ & $25-36$ \\
\hline Canopy shape & $\begin{array}{l}\text { Round, longitudinal, } \\
\text { towering }\end{array}$ & Round \\
\hline Color of trunk & green, reddish-green & Reddish green \\
\hline Leaf shape & Oval, lancet & Ellips to lancet \\
\hline Leaf length $(\mathrm{cm})$ & $15.5-17.2$ & $12.5-18.5$ \\
\hline Leaf width $(\mathrm{cm})$ & $10.4-15.5$ & $9.5-14.2$ \\
\hline Leaf color & Green to dark green & Dark green \\
\hline Leaf surface texture & Coarse & Coarse \\
\hline Leaf edge & Serrated & Serrated \\
\hline Thorn shape & Flat to very concave & $\begin{array}{l}\text { Concave to very } \\
\text { concave }\end{array}$ \\
\hline Thorn color & Brown & Brown \\
\hline Thorn length (mm) & $16-40$ & $6-15$ \\
\hline Trunk & $\begin{array}{l}\text { Flexible, many } \\
\text { branches }\end{array}$ & $\begin{array}{l}\text { Flexible, with a few } \\
\text { branches }\end{array}$ \\
\hline Flower color & Bright yellow & Bright yellow \\
\hline Flower position & Next to thorn & Next to thorn \\
\hline $\begin{array}{l}\text { Fruit circumference } \\
(\mathrm{mm})\end{array}$ & $3.5-4.47$ & $5.01-5.73$ \\
\hline $\begin{array}{l}\text { Weight of } 100 \text { fruits } \\
\text { (g) }\end{array}$ & $3.2-4.31$ & $5.21-5.29$ \\
\hline Young fruit color & Green & Green \\
\hline Ripe fruit color & Red & Red \\
\hline Fruit shape & Round & Round \\
\hline Fruit taste & Very bitter & Bitter \\
\hline Fruit aroma & $\begin{array}{l}\text { Pungent to very } \\
\text { pungent }\end{array}$ & Very pungent \\
\hline $\begin{array}{l}\text { Number of seed per } \\
\text { fruit }\end{array}$ & 1 & 1 \\
\hline Seed shape & Round & Round \\
\hline Seed surface & Soft & Soft \\
\hline Young seed color & White & White \\
\hline Mature seed color & Black & Black \\
\hline
\end{tabular}

\section{Andaliman cultivars}

The local name for andaliman in Salaon Dolok Village is itir-itir or intir-intir. The people of this village generally only recognize two kinds of andaliman cultivars, namely Andaliman 'Simanuk' and Andaliman 'Sihorbo', which are widely grown by farmers in the village. Manuk in Batak language means chicken, while Horbo means buffalo. The morphological characters of the two cultivars are presented in Table 1, Figures 3.A-B.

The Simanuk has a smaller fruit size than that of Sihorbo. Andaliman Sihorbo has larger fruit size, less aromatic and low production. On the other hand, Andaliman Simanuk has smaller fruit size, stronger/more pungent aroma and taste than Sihorbo and have higher production. Generally, farmers in Salaon Dolok planted these two varieties of andaliman. When farmers harvesting these andaliman, they mixed the crops from these two varieties of andaliman. In general, people tend to not know if andaliman have consisted of several varieties.

\section{Timing and techniques of seedling preparation}

Just before the rainy season, the farmers collect the remaining andaliman plants and pruning the old plants which are then piled on the edge of the farmland to be burned. After the farmland is exposed to rain for 2 to 4 weeks, andaliman seedlings usually grow and may reach 20 $\mathrm{cm}$ before they are ready to be planted. Andaliman seedlings are then put in planting holes and covered with soil and organic litter around the roots to maintain the soil moisture around the roots. Then, the seedlings are covered with large leaves to keep the moisture in the soil and to cover the seedlings from direct sunlight exposure.

The planting is usually carried out during the rainy season to reduce the mortality rate of the planted seedlings. To mark the planting spot for andaliman seedlings, local farmers usually use bamboo. The activity of planting andaliman seedling is not conducted simultaneously but it depends on the situation and condition of the land as well as the age of existing andaliman trees. If the farmers have a lot of spare land, the farmers usually multiply andaliman planting. If many andaliman trees are old and considered unproductive, the plants will be replaced and andaliman planting will be carried out again. The cultivation of andaliman does not use fertilizers, and it is because of two reasons. First, they consider that the soil is fertile enough to support andaliman growth. Second, local farmers recognize andaliman as wild plants that originated from the forest, so people believe that fertilizers are not really needed for andaliman growth. Thus, in this traditional farming context, andaliman growth is very dependent on soil fertility and sufficient rainfall.

Rainfall is considered as a crucial factor for andaliman cultivation by local farmers. This andaliman plant is very susceptible to prolonged dry season and direct sun exposure. The dropping of the leaves characterizes dry andaliman plants. Therefore, andaliman plant needs shade to support this plant growth. Local farmers usually plant andaliman under pine trees, incense trees, tusam trees, or rubber stands, which protect from sunburn caused by direct sunlight exposure.

\section{Land preparation and Marsiadapari}

Andaliman planting area is located in forests, farm fields, or a small part of plantation area. The ideal area for planting andaliman should be land with fertile soil, enough shades, appropriate land slope, appropriate altitude, and considerable distance from the settlement. Infertile soil is characterized by it yellow color and hard structure and texture, while fertile soil is characterized by black/dark color soil with a fine texture. Before planting, it is necessary to clear the land and clear the weeds (Figure 2.B) so that they do not interfere with the planting process and the land becomes clean. 

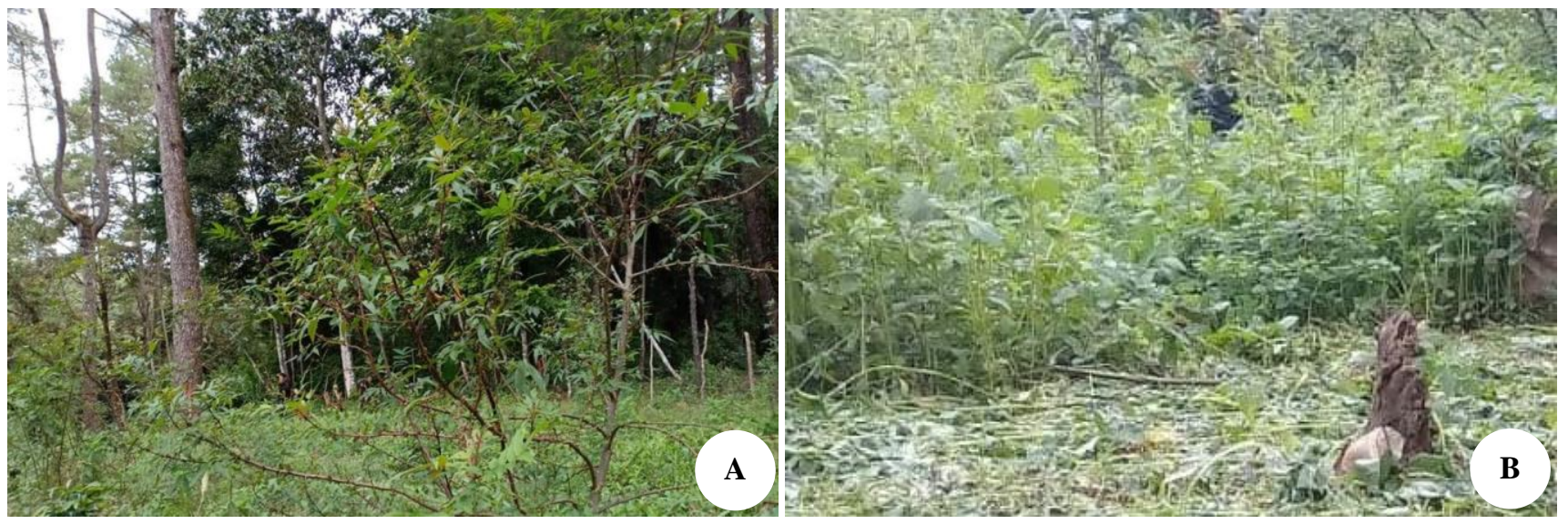

Figure 2. A. Cultivate andaliman as part of agroforestry system that planted under pines trees in Samosir Protected Forest. B. Before planting, it is necessary to clear the land and clear the weeds
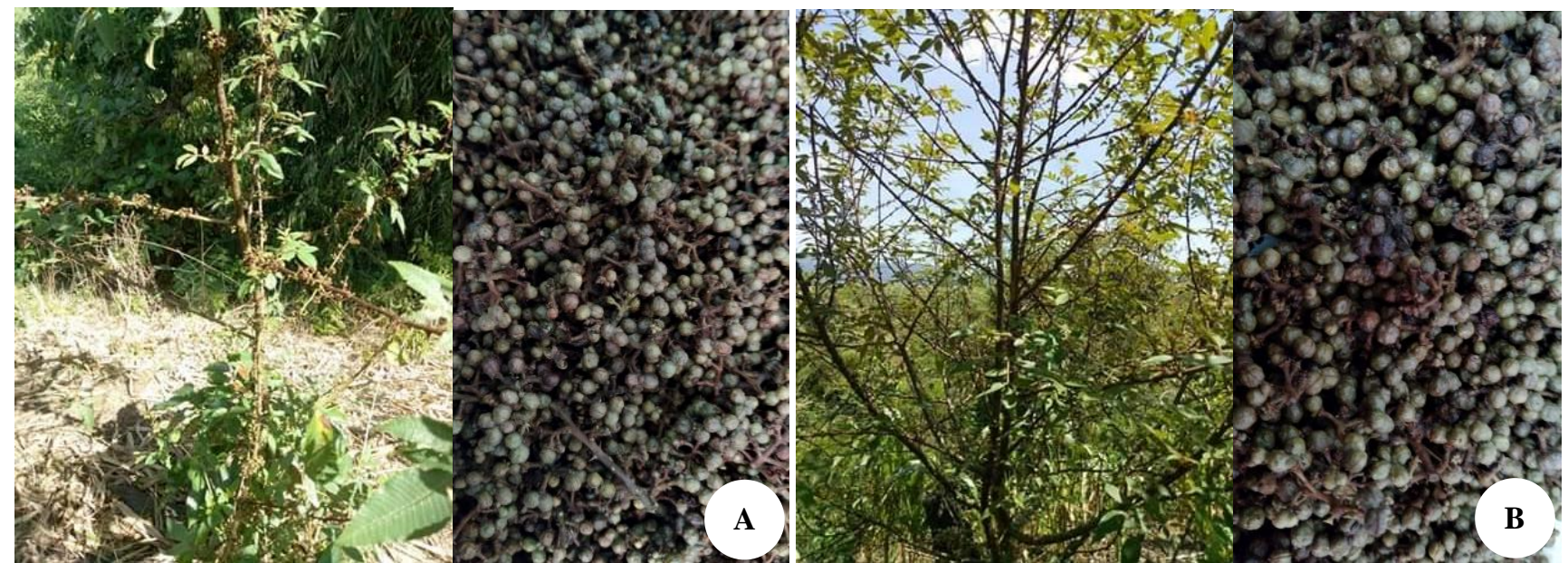

Figure 3. Andaliman cultivars. A. Simanuk, B. Sihorbo

According to Siahaan (2018), the physical properties of soil that is ideal for andaliman growth are clay and claydominated soil fraction, fine soil texture, low soil content weight but with high soil porosity. The ideal soil chemical properties for andaliman growth are moderate to high organic matter content of $\mathrm{C}$ and $\mathrm{N}$, very acidic to acid soil $\mathrm{pH}$, and moderate to high CEC soil. Based on the interviews, local communities around Lake Toba argued that the area around Lake Toba has agricultural land with certain soil layers that are different from other areas. They believed that this unique soil content came from eruption materials of Mount Toba thousands of years ago.

The processing of land preparation of andaliman farmland in Salaon Dolok Village has changed in the way of people involved. In the past, the community carried out land management with mutual assistance called marsiadapari. Marsiadapari activities are carried out in a reciprocal manner and are usually carried out during land clearing, farming and harvesting. The people who help are not given any wages in the form of money, but the initiator will return to work in the garden/field of the person who has helped him/her according to the time when the person needs assistance. The forms of marsiadapari in the Toba Batak community include: (i) mangimas, clearing forests or shrubs that are used as agricultural areas or rice fields, (ii) mangarambas, cutting down after trees are cut down, (iii) mangombak, the process of turning the soil layer over, as well as to loosen the soil, (iv) manggadui, the process of patching the muddy soil around the rice fields (gadu gadu), (v) naming, refers to seeding activity, (vi) manggaor, flattening the soil and at the same time loosening it, (vii) marsuan, namely planting, (viii) marbabo, taking care of plants from the weeds, and the last stage is (ix) gotilan that refers to harvesting.

Marsiadapari is mutual cooperation that is implemented in agriculture mostly to work on rice/paddy fields. According to local relevant respondents, the tradition of mutual cooperation (marsiadapari) has become part of the life practice of the Toba Batak people to reduce life problems and this tradition has been passed through many generations since ancient times. The tradition of mutual cooperation is essentially an ancestral heritage. 
Currently, only a small proportion of the community is still practicing marsiadapari. Most local farmers in Salaon Dolok conducting land management and preparation by involving their families and relatives. Nowadays the local wisdom of gotong royong is increasingly fading because payment in the form of money wage is rather expected, and mutual cooperation is no longer needed. This mutual cooperation must continue to be carried out in people's lives in order to create cooperation that can create cohesiveness, and will be useful in the future as a legacy for future generations. Several people of Salaon Dolok Village still carry out the marsiadapari tradition which is considered as a legacy from their ancestors.

\section{Seed germination and seedling preparation}

The activity of seedling preparation is carried out very simply with at least three different methods. The simplest method is that farmers collect andaliman seeds that grow wild around the existing andaliman plants (Figure 4.A). The second method is by burning land with some remains of old andaliman plants that are collected at the edge of the land. After the land is burned or the andaliman plant remains are burned, several weeks to a month later andaliman seedlings will grow around the burning site. Some relevant respondents stated that andaliman grows by itself on vacant lands that have just been opened into agricultural land after land clearing is carried out. The collected seedlings for planting is the seedling that has three leaves with a height of about $20 \mathrm{~cm}$ (Figure 4.B).

In Salaon Dolok Village, farmers generally rely on wild-growing seedlings because they are considered more resistant and bear fruit quickly. Several farmers have tried to make a nursery from the seeds of the previous harvest. However, after the seedlings grew two leaves, most of these seedlings died and the survived seedlings tend to be less fertile and unproductive. Based on the interview results with relevant farmers who grow the seedlings in the wild, they said that the wild seedlings are more resilient. Several farmers conducted seedling propagation from seed sowing in the nursery, but most of the seeds planted did not sprout. Even if they grew and became seedlings, the growth rate was very slow, and the seedlings will die before it can grow further to become adult trees. Farmers in the andaliman nursery still rely on seeds that grow wildly in the forest, seeds that grow after burning the land, seeds that grow after burning dead plant debris, and seeds that grow independently under the main plant.

The main cause of the andaliman seed germination difficulties is thought to be related to the low germination rate of this species and the seed dormancy aspects. The hard structure of the seed coat can inhibit germination by blocking water imbibition and gas exchange. In the form of a terpenoid compound found in andaliman (Siahaan 2000; Wijaya 1999; Wijaya et al. 2002), the volatile component is known to be a germination inhibitor compound (Hess 1975). Several studies on andaliman germination have been carried out, including germination and seed dormancy breaking (Siregar 2013; Batubara et al. 2018) but the results were not satisfactory.

\section{Planting of seedlings}

The seedlings planting is carried out when the seedlings already have three leaves with a height of approximately 20 $\mathrm{cm}$. The seedlings are transferred to the planting hole that has been prepared for andaliman planting. Planting new seedlings is carried out mostly to replace old plants or replace seedlings that have died due to drought or pests.

The distance between one planting hole with the others varies between $3 \mathrm{~m}, 4 \mathrm{~m}, 5 \mathrm{~m}$, or $10 \mathrm{~m}$. The distance is determined based on the fertility of the land. If the land is fertile, the distance between planting hole can be further, e.g., $10 \mathrm{~m}$. In the fertile soil conditions, andaliman will grow faster and bigger, requiring long distances between planted seedlings. The main purpose of adjusting the distance between planted seedlings (spacing) is to provide distance between trees and andaliman trees so that they can be easily controlled, cared and harvested (Figure 4.C).

After planting the seedlings, the main part of the seedling stems is then covered with leaf litter to keep the plants in moist condition. Local farmers also provide shades for the andaliman seedling by covering it with large leaves, such as banana leaves. Most of the interviewed farmers stated that andaliman is susceptible to direct sunlight. For this reason, when the new wild seedlings planted, they usually covered it with large leaves. In andaliman agroforestry model in Samosir Protected Forest, farmers planted the seedlings under the shade of large trees such as Pine (Pinus merkusii), Kayu Putih (Melaleuca spp.), Attarasa (Litsea cubeba), and other large trees. Andaliman is usually planted in the forest or on the edge of the forest with a specific habitat profile, namely areas with a steep slope and slightly shaded (Nurlaeni and Junaedi 2018).

\section{Fertilizing}

In general, andaliman farmers in Salaon Dolok Village do not utilize fertilizer at all from the beginning of andaliman planting until they grow big. This is considered one advantage of planting andaliman in which farmers do not have to pay for fertilizer. Based on the interviews with local farmers, andaliman should not be fertilized by animal manure, because it can cause andaliman to become wither. Farmers only accumulate forest litter and put it near the andaliman main stem. Farmers also do not conduct routine maintenance to control the weeds as well as do irrigation. The watering for andaliman relies on rainfall only. 


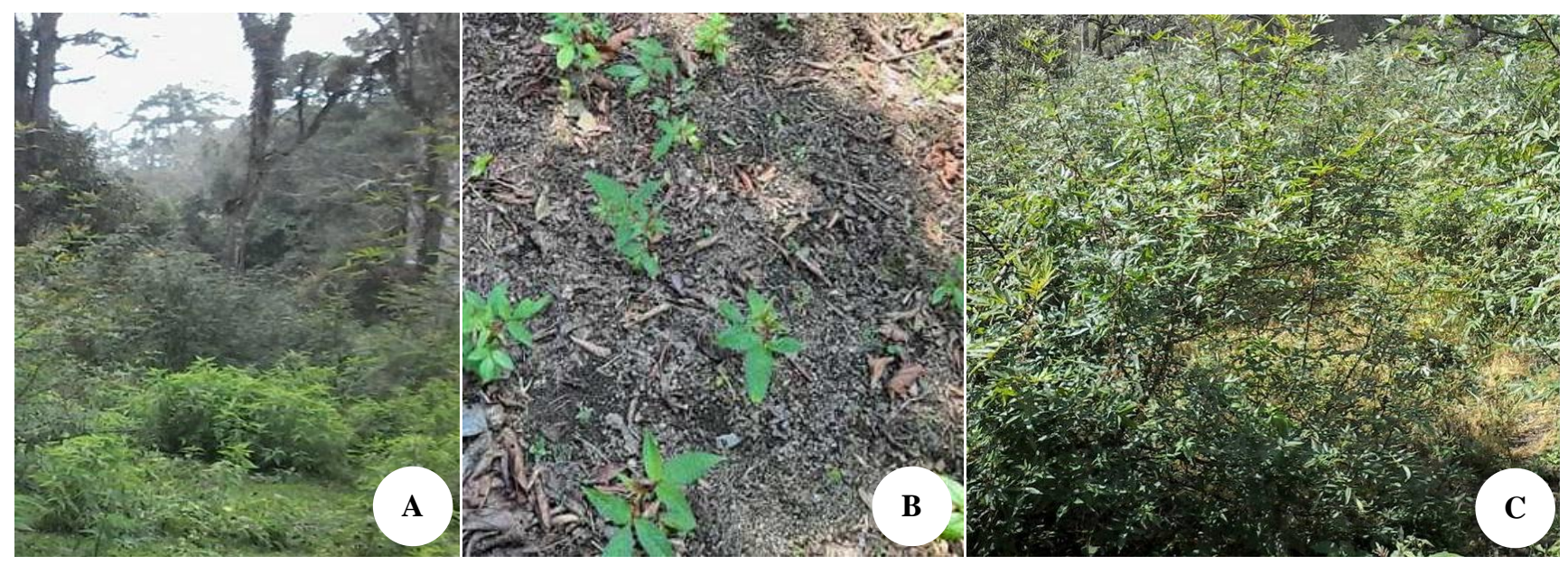

Figure 4. A. Farmers collect andaliman seeds that grow wild around the existing andaliman plants. B. The collected seedlings for planting is the seedling that has three leaves with a height of about $20 \mathrm{~cm}$. C. The main purpose of adjusting the distance between planted seedling (spacing) is to provide distance between trees and andaliman trees to be easily controlled, cared and harvested. I changed the Figure B

The role of trees in the nutrient cycle is to absorb nutrients from the soil and release nutrients back through dead or harvested tissues. The dead tree tissues then decompose and produce simple compounds back into the soil. In addition, some plant tissue that has died and has fallen to the ground can become a source of food for some living things. The nutrient elements in the dead tissue are returned to the soil through the dirt or after the living thing has died. The parts of the tree that are most often shed and decomposed are leaves. The release of nutrient elements due to the decomposition process increases soil fertility, increases fertility through the addition of nutrients, leaves fall under the trees, and increases the number of soil animals that are useful for soil aeration (Hartono, 2012 in Wowor et al. 2020).

The plant species mixing in a planting system significantly affects the nutrient cycle that occurs in an ecosystem, such as community-managed forests. Community forest management usually combines several species that are considered beneficial between seasonal crops and perennials and co-perennials. Trees are a large litter producer and play an important role in maintaining and restoring soil fertility, especially in agroforestry planting systems. According to Boesten et al. (2010), most of the litter consists of dead plant material and is found on the soil surface, and ecologically the litter layer is the main component of the land ecosystem which is the source of soil organic matter and as a place for soil biological processes such as decomposition and initiation of a nutrient cycle.

The fall and decomposition of tree litter in agroforestry systems is considered an important factor contributing to soil quality. Nutrient input from litter plays an important role in maintaining soil fertility and primary productivity of forest ecosystems (Gnankambary et al. 2008). The accumulation of litter will provide a habitat and food source for micro and macroinvertebrates, which are important in the food chain (Sangha et al. 2006).
Evaluation of litter production is essential in understanding nutrient cycling, forest growth, and interactions with environmental factors in forest ecosystems. Thus, the plant species composition will affect the cycle of organic matter and nutrients in a community forest. This nutrient cycle affects soil fertility level because the quality of the litter produced strongly influences the nutrients input to soil from plants. Litter production and litter decomposition play a major role in the dynamization and nutrient cycling of forest ecosystems. The release of nutrient elements due to the decomposition process increases soil fertility, either through the addition of nutrients from litterfall or soil aeration (Tripathi and Tripathi 2009; Tjitrosemito et al. 2011; Wowor et al. 2020).

\section{Maintenance}

Maintenance is very important to prevent pests and diseases attack to support optimum growth of andaliman. Maintenance usually done by farmers is by periodical cleaning of the weeds. The ways of andaliman maintenance practiced by local farmer are quite unique. Farmers do not clear the weeds located near the andaliman roots because they consider that the roots of andaliman are very sensitive. Weeds that grow around the andaliman trunk must be cleaned carefully and sometimes they do not clean it to avoid disturbance to andaliman roots. Based on the farmer statement, when they clean the weeds around the trunk and near the roots, andaliman will eventually wither over time. Based on this experience, farmers rarely remove weeds that grow around the root area. Furthermore, pesticides for pests and diseases are never used because according to the farmers statement, the andaliman plants are rarely attacked by pests and diseases. Some common pests include small number of ants and leaf-worms, so it can still be removed manually. There is also a fungus in the form of a white spot on the main stem, but the farmers usually remove the affected part manually. 


\section{Harvesting}

Andaliman can produce fruit at the age of 1.5 to 2 years after planting (Figure 5.A). The young andaliman fruit is green, and becomes red when its ripe, and black when its dry. The andaliman fruit that already green and as big as pepper size can be harvested. Harvesting is done manually by hand-picking. Andaliman picking requires high concentration and most painstaking, because of the thorns on the stem. Women mostly carry out the andaliman harvesting processes because it requires patience due to the thorns on its stem. Care is needed during the harvesting process because andaliman's thorns may cause fever.

To some extent, the harvested andaliman fruits are also adjusted based on consumer demand. Some consumers ask for green andaliman fruit for restaurants serving Bataknese specialties, direct-sold to the market, and for bandrek producers. On the other hand, there are also consumers who ask for red fruit to be used as andaliman powder and other andaliman derivative products. According to interviewed farmers, villagers and consumers, andaliman from Samosir is considered as unique variety compared to other andaliman from other regions due to its very distinctive taste (stronger). The type of soil may cause the general opinion about this distinctive Samosir andaliman taste in the Samosir area which contains volcanic ash from Mount Toba.

An andaliman tree can produce approximately $0.5 \mathrm{~kg}$ $2 \mathrm{~kg}$ in one harvesting time. In average, a tree can produce $10 \mathrm{~kg}$ andaliman fruit per year from several harvesting times. Harvesting activity is carried out once in a week. Old ripe andaliman fruit must be removed from the tree. Otherwise, the part of the stem where the old ripe fruit was not taken will eventually die. The total andaliman harvested will change along with the age of the andaliman tree itself. In the early harvesting years, the production may reach $0.5 \mathrm{~kg}$ per tree on average. This yield will continue to increase as the plant grows until it reaches its peak harvest period at 2.5 to 5 years after planting, with an average production of $20 \mathrm{~kg} /$ year and will gradually decline after five years.

In general, the harvesting activities are carried out conventionally using the marsiadapari tradition. Usually, the peak season of the andaliman harvesting period starts from March to July. When the andaliman price is high, the farmers will try to harvest it twice a week. In contrast, if the price of andaliman is cheap, the farmers will adjust the harvesting frequency to once in two weeks. To reach the fruit on the higher branch, a plastic chair or wooden chair is used as a ladder. There is also a customized hook called hait-hait (a dried tree branch with a number 7 shaped) to hook the tall branch so that it can be lowered and easier for farmers to harvest the fruit. Farmers usually use buckets, plastic baskets, or bamboo baskets called karajjang to carry the fruit harvested (Figure 5.B). The farmers use banana leaves on the container base to maintain the fresh condition of andaliman fruits. Once the andaliman packaged, then it is ready to be sold immediately. The crops are directly sold to buyers or to the toke (collectors).

Existing weather conditions significantly influence the obtained andaliman fruit yields. Based on the results of interviews with the andaliman farmers, more yields are obtained during the rainy season and vice versa. When the dry season coming, the yields will significantly decrease and may cause some andaliman trees to die. Farmers will immediately replace the dead plants with new seeds when the rainy season arrives. Andaliman fruit should not be harvested when it rains, because the crop will be exposed to water or rain that caused the fruit to ripen and turn black quickly and cannot be sold. During the dry season, the farmer's income will significantly increase because the farmers will be more frequent to conduct harvesting in their fields during this season. Apart from these factors, the income of andaliman farmers is also influenced by market prices. At the peak season of andaliman harvesting time, the crop production will increase and also will affect andaliman market prices. The andaliman farmers hope that there will be a standard reliable price for this crop to avoid drastic fluctuation of andaliman prices.

\section{Post-harvesting}

Agricultural products have the perishability characteristic, so they need post-harvest treatment. The harvested andaliman fruits are usually brought from the garden to the house. The fruits are then dried by wind at room temperature by placing the fruits evenly on a tarp, mat or wide cloth in a room that is not exposed to direct sunlight (Figure 5.C). This process aims to reduce the moisture of andaliman fruits, so it will stay fresh and not be rotten quickly.

The quality of the fresh andaliman fruits will decrease if they are stored for a long time. This quality reduction will happen rapidly if the fruits stored at room temperature than if stored at cold temperatures. Usually, at room temperature andaliman crop will decompose within ten days. The decaying process of andaliman begins with the growth of mushroom mycelium on the fourth or the fifth day after harvest. At this stage, the andaliman fruits still taste like fresh andaliman though. On the tenth to the fourteenth day, andaliman's color turns black and not suitable for consumption anymore, the aroma and the bitter taste will be disappeared so that the crop quality drops significantly.

It is necessary to find alternative ways to preserve andaliman fruits. The commonly recognized way to extend the shelf life of food is by drying method. However, since spices, including andaliman, contain volatile compounds that are easily damaged by heat treatment, the drying method is not recommended for andaliman fruits to minimize the losses of the distinctive flavor of these spices that originated from its volatile compounds.

Fresh fruit products are basically living tissues. Therefore, the respiration process is still ongoing in it. The respiration process that occurs after harvesting is very fast, especially because the crop is not anatomically related to the roots or stems anymore that used to supply moisture to the fruits. Thus, physical and physiological damage occurs more quickly. Fruit commodities can be stored for a long time after harvesting, however, several things can decrease the quality of the fruit due to several post-harvest diseases caused by microorganisms such as fungi, bacteria, and viruses. One of the causes of the post-harvest disease is a 
group of pathogenic fungi (Phoulivong et al. 2012) and will cause rot in the fruit (Al-Najada and Al-Suabeyl 2014).

Andaliman farmers in the village of Salaon Dolok have local wisdom in post-harvest andaliman handling. The dried andaliman fruits are packed and wrapped in banana leaves or put in plastic bags/sacks with pieces of banana leaves inside the bags. The banana leaves can minimize physical damage to the packed fruits during transportation. Some farmers add cayenne pepper to the plastic bags/sack to keep the andaliman fruits stay fresh (Figure 5.D).

For sales in small quantities, the seller usually puts andaliman fruits into $600 \mathrm{~mL}$ plastic bottle with each bottle contains $250 \mathrm{~g}$ of andaliman fruits (Figure 5.E). Meanwhile, for shipments outside the city in large quantities, they are packed with cardboard boxes or bamboo baskets and placed banana leaves at the bottom, around, and the upper part of the boxes/baskets to avoid physical damage during transportation. The baskets are closed with a tarp and tied neatly.

\section{Marketing}

After andaliman fruits are harvested and processed, the next process is marketing. andaliman's packaging process is not complicated because it is only simple packaging using plastic bags. The farmers directly sell them at the closest market from Salaon Dolok located at Tomok which only opens once a week, on Wednesday. In Bataknese language, the market is called pajak, or pekan or onan because the market in Samosir opens once in a week (pekan = week). Onan is a very important medium in the Toba Batak community. Apart from conducting economic transactions, it also has a sociological value to communicate with each other and provide important information about events in the community.

When price is rising, farmers in Salaon Dolok often sell their crops directly to the market because it is more profitable. Farmers carry their crops using motorbikes to the market. In contrast, if the andaliman price is very low, the farmers sell the crops to the toke (the term for traders who come to the village and buy crops from farmers) because going to the market will require time and travel costs. The margin between the andaliman market price and the toke price ranged from Rp. 5,000 to Rp. 10,000 per kg.
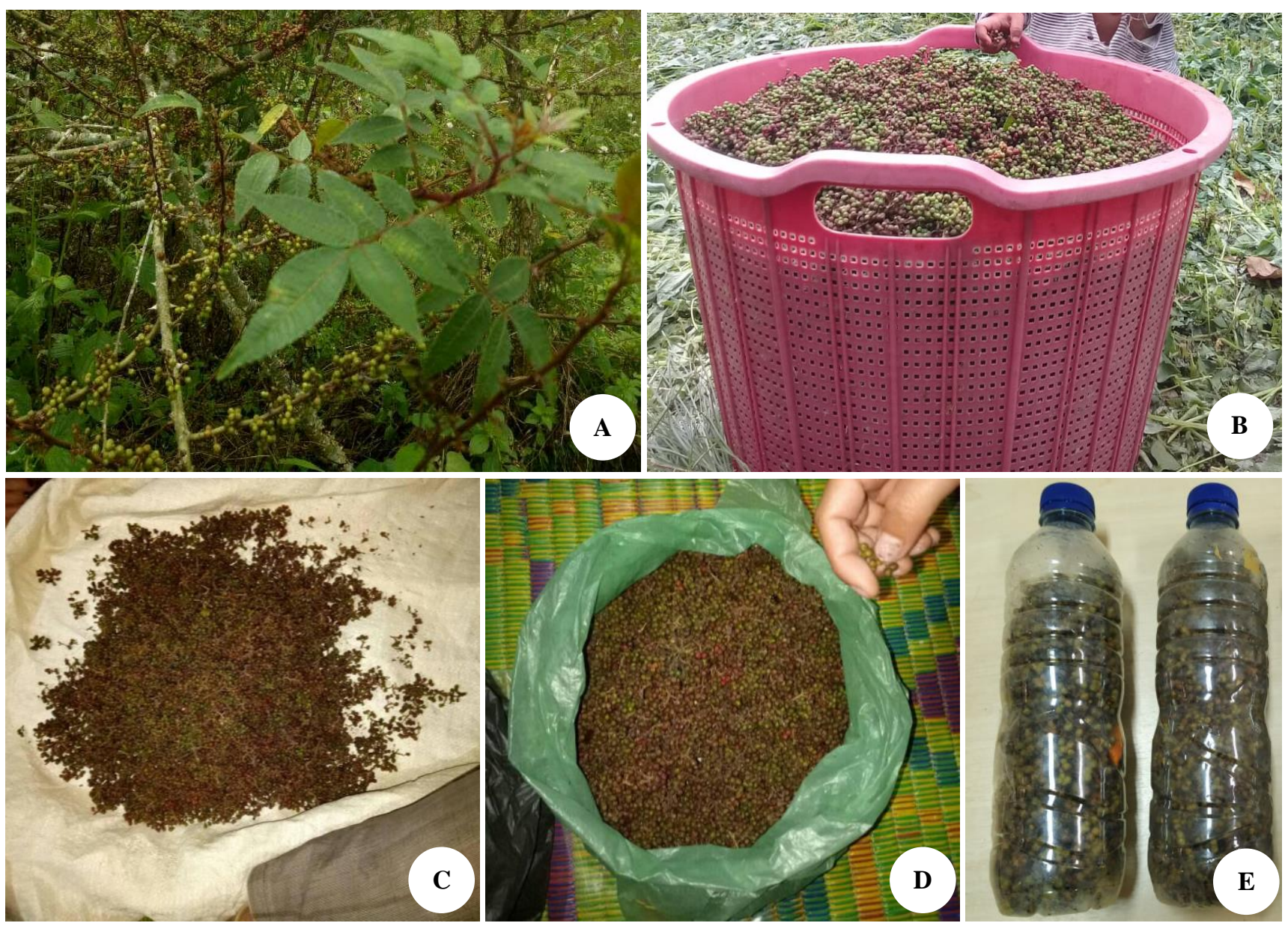

Figure 5. A. Andaliman can produce fruit at the age of 1.5 to 2 years after planting. B. The use of plastic baskets to carry andaliman fruits during the harvesting. C. The fruits of andaliman are being dried by wind (wind-dried). D. The dried andaliman fruits are packed and wrapped in banana leaves or put in plastic bags/sacks with pieces of banana leaves inside the bags. E. Andaliman fruits into $600 \mathrm{ml}$ plastic bottle with each bottle contain $250 \mathrm{~g}$ of andaliman fruits. Farmers add cayenne pepper to the bottle to keep the andaliman fruits stay fresh 
Andaliman farming is profitable for farmers. One of the main reasons is that andaliman does not require a lot of time to cultivate and the maintenance is relatively simple. The price of andaliman in the market has fluctuated but the farmers still consider andaliman farming is profitable. For example, in December 2020 andaliman sales price reached Rp. 370,000 per $\mathrm{kg}$. andaliman prices usually start to increase in October. The highest price occurs from December to January. Farmers will get profit, because during these months the andaliman market demand increases due to traditional events, Christmas and New Year celebrations, as well as weddings. Andaliman is needed for various cooking spices, so people will buy them in large quantities. Meanwhile, from February to August, the andaliman price may reach Rp. 10,000 to $\mathrm{Rp} .15,000$ per $\mathrm{kg}$. However, farmers said that selling andaliman is still profitable even at the lowest market price period because andaliman does not require intensive maintenance and does not use fertilizers and pesticides, so the production costs are very low.

The traders who buy andaliman crop at district level market will sell it to the provincial level or export andaliman abroad. The marketing of andaliman is increasingly widespread in cities where there is significant population of Batak ethnic communities such as Jakarta, Pekan Baru, Batam, Medan, Siantar, Surabaya, Bandung and Makassar. Due to the increasing demand and promising economic prospects of andaliman, many toke are starting to come to this Salaon Dolok to buy andaliman to be marketed outside the area such as Pematang Siantar, Medan and its surroundings. Several farmers turn to become toke who come to the village to buy and collect andaliman crops by car then immediately sell it to Pematang Siantar, Medan and its surroundings.

\section{The sustainability of andaliman cultivation in Salaon Dolok Village}

Sustainable agriculture is a part of the concept of sustainable development introduced in the World Conservation Strategy published by the United Nations Environment Program (UNEP) in 1980. Various definitions of sustainable development have been raised, but the definition generally accepted by the international community is as compiled by Brundtland Commission: "the development to meet current needs, without reducing or destroying the ability of future generations to meet their daily needs" (United Nations, 1987; Langhelle 1999). Agricultural activities can be considered as sustainable if they include the following: (i) ecologically stable, which means that the quality of natural resources is maintained and the capacity of the agro-ecosystem is increased; (ii) Economically sustainable, which means that farmers can generate enough of their income to meet their needs; (iii) Fair, which means that resources and power are distributed in such a way that the basic needs of all community members and their rights to use the land are met, including access to capital, technology and marketing, as well as opportunities to participate in decision making; (iv) Humane, that is, all forms of life and the basic dignity of all living things are respected; and (v) Flexible, which means that the community can adapt to changing farming conditions (Reijintyes et al. 1992; Sudalmi 2012).

The andaliman farming system in Salaon Dolok Village is a traditional farming system. The community has local knowledge related to the management of reliable agricultural systems from generation to generation. andaliman cultivation in Salaon Dolok Village does not need maintenance costs for fertilizers and pesticides. In general, andaliman planting is mostly done in the forest. Planting andaliman in the forest is considered more fertile, grows faster, produces more crops and has a longer growing period of up to 20 years. When compared to planting in slow-growing fields, the yields are lower, and plant life is shorter, which is only 5 years. Andaliman growth is very dependent on soil fertility and sufficient rainfall. In general, andaliman farmers in Salaon Dolok Village do not provide fertilizer at all from the beginning of planting until they grow up. Forest litter can be a natural fertilizer for reliable growth. The presence of understorey greatly helps plantation forest vegetation grow by protecting the soil and soil organisms and helps create a microclimate on the forest floor and maintain soil fertility. Pesticides for pests and diseases are never used because according to andaliman farmers it is rarely attacked by pests and diseases. Some of the pests that attack are usually ants and leafworms, which are small in number so they can still be taken manually. There is also a fungus in the form of a white spot on the main stem, and the way to overcome it is by removing the affected part manually. Andaliman agriculture uses minimal pesticides so it does not leave chemical residues in the ecosystem. Andaliman farming is profitable for farmers since this farming does not require a lot of time to cultivate it and the maintenance is not difficult.

Sustainable agriculture should also minimize the external input from outside the agro-ecosystem. Low External Input Sustainable Agriculture (LEISA) emphasizes the efficient use of existing production factors to create sustainable agriculture. LEISA is a system that optimizes the use of natural resources and reduces input from outside, to increase productivity and income by considering the balance of the ecosystem. LEISA uses the right methodology to strengthen the capacity of the community in order to improve the quality of agriculture that combines local knowledge, scientific and new innovations for sustainable agriculture (Reijintyes et al. 1992).

Since decades ago, farmers in Salaon Dolok Village have been practicing agriculture by accounting for nature sustainability and community togetherness to raise values related to human-creator, human-human, and human-nature relationships. Mutual cooperation in the agricultural activities of the Toba Batak community (marsiadapari) is a form of mutual assistance in agricultural activities. The results of each work or activity will produce something useful for agricultulre purposes. The results of marsiadapari are mainly aimed at the interests of individual participants, which can be enjoyed by all 
participant members. This is because marsiadapari activities involve labor and the results that are immediately manifested are physical and non-physical. In physical form, it can be seen that marsiadapari can accelerate the completion of field jobs.

There are seven concepts of mutual cooperation in the Toba Batak community. The concept of mutual cooperation includes mutual understanding, mutual agreement, mutual support, mutual assistance, jointly planning, working together, and working together on the same work. Mutual cooperation or mutual assistance is developed in tradition because of the need to solve a particular problem faced by a community and speed up the completion of a job or an issue (Sibarani 2018).

Traditional conservation in Salaon Dolok communities that based on environmental values and wisdom, has proven to be able to sustain their lives for centuries in the local environment they live in. This is very relevant and important example as an alternative example of humannature relationship that is not destructive. Conservation principles have been crystallized in various forms of traditional wisdom, and have been developed and implemented in various forms of practice applied by the community. Nature conservation principles are adapted from their experiences in harmony with nature. These experiences are then compiled and disseminated to all community members to serve as a guide. However, as time goes by, currently only a small part of the community is still doing marsiadapari in Salaon Dolok Village.

According to Nababan (1995) traditional cultures, especially in terms of natural resource management had particular conservation principles including: (1) Respect that encourages harmony in the human relationship with the natural surroundings; (2) Sees itself as a part of nature itself; (3) The feeling of exclusive ownership of the community over a certain area or natural resource as a communal property resource. This sense of belonging binds all citizens to safeguard and secure this shared resource from outsiders; (4) A local knowledge system that gives the community the ability to solve problems they face in utilizing its limited natural resources; (5) Adaptability in the use of simple technologies that are efficient and energyefficient according to local natural conditions; (6) An allocation system and enforcement of customary rules that can secure shared resources from overuse, both by the community itself and by outsiders (migrants).

Management and cultivation of andaliman in Salaon Dolok Village is based on the traditional ecological knowledge of the local community. Tradition is local wisdom that is included in the form of culture. Tradition as the identity of society in each area has been carried out from generation to generation from one generation to the next. The traditional agricultural system cannot be separated from the local wisdom of the community, which links agriculture with culture. Agricultural systems and community cultures are interrelated. Village communities generally still carry out culture in the form of a tradition in farming activities. Culture in agriculture must be preserved so that local wisdom is well preserved. Based on years of farming experience, andaliman farmers stated that the forest is very suitable for the location of andaliman's planting. The topography of the village of Salaon Dolok is hilly and has a tropical climate. The community believes that the forest provides life for the surrounding community economically and spiritually. Forests as part of the environment, their existence must be preserved as well as possible. The community carries out forest management as an effort to protect, fulfill their daily needs, social integration, education, trust and self-actualization. Therefore, the government involves the community to manage the forest. The community is given permission to plant in a deforested area on the condition that they do not cut trees and continue to preserve the forest. In terms of regulation, forest resource management has been regulated in such a way in order to improve the welfare of the community around the forest. Management of forest resources based on traditional ecological knowledge encourages the creation of sustainable forest resources. Local knowledge about the management and cultivation of andaliman can contribute to the development of andaliman cultivation practices that will support the economic growth of farmers, due to the commercialization of andaliman as a spice crop commodity to domestic and export needs. However, the commercialization of andaliman must consider environmental sustainability.

\section{ACKNOWLEDGEMENTS}

Publication of this article was financially supported by the University of Padjadjaran ALG (Academic Leadership Grant) Program, a research program Prof. Johan Iskandar. The authors are thankful to the Rector of the University of Padjadjaran for supporting ALG program. The authors thank all those who contributed to this study, especially the local people of Salaon Dolok Village for the information provided.

\section{REFERENCES}

Al-Najada AR, Al-Suabeyl MS. 2014. Isolation and classification of fungi associated with spoilage of post-harvest mango (Mangifera indica L.) in Saudi Arabia. Afr J Microbiol Res 8 (7): 685-688. DOI: 10.5897/AJMR12.1898

Albuquerque UP, da Cunha LVFC, De Lucena RFP, Alves RRN. 2014. Methods and Techniques in Ethnobiology and Ethnoecology. Humana Press, New York.

Anggraeni R. 2019. Uji karakteristik simplisia buah andaliman (Zanthoxylum acanthopodium DC.). Jurnal Ilmiah Farmasi Imelda 3 (2): 34-40. [Indonesian]

Arsita EV, Saragih DE, Aldrin K. 2019. Anticancer potential from ethanol extract of Zanthoxylum acanthopodium DC. seed to against MCF-7 cell line. IOP Conf Ser: Earth Environ Sci 293 (1), 012016. DOI: 10.1088/1755-1315/293/1/012016

Batubara M S, Ginting N, Ariaji R. 2018. Pengabdian kepada masyarakat "Bimbingan iptek dan pelatihan proses perkecambahan biji tanaman andaliman (Zanthoxylum acanthopodium Dc.)" di Desa Sitaratoit. Martabe: Jurnal Pengabdian Kepada Masyarakat 1 (3): 33-41. DOI: 10.31604/jpm.v1i3.133-141

Boesten J, Bolognesi C, Brock T, Capri E, Hardy A, Hart A, Hirsch-Ernst K, Bennekou SH, Luttik R, Moretto A. 2010. Scientific opinion on the importance of the soil litter layer in agricultural areas EFSA panel on Plant Protection Products and their Residues (PPR). EFSA J 8(6), 1625 
Devi O, Rao K, Bidalia A, Wangkheirakpam R, Singh O. 2015. GC-MS analysis of phytocomponents and antifungal activities of Zanthoxylum acanthopodium DC. collected from Manipur, India. Eur J Med Plants 1-9. DOI: $10.9734 /$ ejmp/2015/19353

Faradillah F, Santi MA, Sipahutar LW, Nurmi A, Mahmud A. 2020. Effects of andaliman (Zanthoxylum acanthopodium DC) supplementation on broiler immunity. J Phys: Conf Ser 1477 (7) DOI: 10.1088/1742-6596/1477/7/072009

Gnankambary Z, Bayala J, Malmer A, Nyberg G, Hien V. 2008 Decomposition and nutrient release from mixed plant litters of contrasting quality in an agroforestry parkland in the south-Sudanese zone of West Africa. Nutri Cycl Agroecosyst 82 (1): 1-13. DOI: 10.1007/s10705-008-9165-3

Hanum IT, Laila L. 2018. Evaluation of anti-aging and anti-acne effect of andaliman (Zanthoxylum acanthopodium DC.) ethanolic extract peel off gel mask. Asian J Pharm Clin Res 11 (13), 90 https://doi.org/10.22159/ajpcr.2018.v11s1.26576

Harahap U, Hasibuan PAZ, Sitorus P, Arfian N, Satria D. 2018. Antimigration activity of an ethyl acetate fraction of Zanthoxylum acanthopodium DC. fruits in 4T1 breast cancer cells. Asian Pac J Cancer Prev 19 (2), 565. DOI: 10.22034/APJCP.2018.19.2.565

Harsono T, Kurniawan AS, Prakasa H, Syahfitri D, Husna F, Prasetya E. 2016. Analisis spasial geografi dan maximum entropy untuk menentukan zona konservasi in situ pada Andaliman (Zanthoxylum acanthopodium DC.) di Sumatera Utara.

Hartley T G. 1966. A revision of the Malesian species of Zanthoxylum (Rutaceae). J Arnold Arboretum 47 (3): 171-221.

Hasairin A. 1994. Etnobotani Tanaman Rempah dalam Makanan Ada Masyarakat Batak. Angkola dan Mandailing [Tesis]. Program Pascasarjana IPB, Bogor, Indonesia. [Indonesian]

Hasairin A. 2014. Variasi, keunikan dan ragam makanan adat etnis batak toba suatu kajian prospek etnobotani. Jurnal Pengabdian Kepada Masyarakat 20 (75): 21-26. [Indonesian]

Hess D. 1975. Alkaloids. Plant Physiology. Springer.

Junaedi DI, Nurlaeni Y. 2019. Ecology of Zanthoxylum acanthopodium Specific leaf area and habitat characteristics. Biodiversitas 20 (3): 3237. DOI: $10.13057 / \mathrm{biodiv} / \mathrm{d} 200317$

Karnady V. 2015. Comparison on In Vitro Digestion Effect of Antioxidant and Antihyperglycemic Activity from Andaliman (Zanthoxylum acanthopodium DC.) and Japanese Pepper (Zanthoxylum piperitum DC.) Crude Extract. [Graduate Thesis]. Bogor Agricultural University, Indonesia. [Indonesian]

Kristanty RE, Suriawati J. 2014. Cytotoxic and antioxidant activity of petroleum extract of Andaliman fruits (Zanthoxylum acanthopodium DC.). Int J PharmTech Res 6 (3): 1064-1069.

Langhelle O. 1999. Sustainable development: exploring the ethics of our common future. Int Pol Sci Rev 20 (2): 129-149.

Lestari NS, Levina L. 2018. Uji kesukaan saus arrabbiata menggunakan bumbu tradisional andaliman. National Conference of Creative Industry 102-113. DOI: 10.30813/ncci.v0i0.1204 [Indonesian]

Nababan 1995. Kearifan tradisional dan pelestarian lingkungan di Indonesia. Jurnal Analisis CSIS: Kebudayaan, Kearifan Tradisiona dan Pelestarian Lingkungan. Tahun XXIV No. 6 Tahun 1995 [Indonesian]

Napitupulu FIR, Wijaya CH, Sulistiyani, Prangdimurti E, Akyla C, Yakhin LA, Indriyani S. 2020. Comparison of several processing methods in preserving the flavor properties of andaliman (Zanthoxylum acanthopodium dc.) fruit. J Eng Technol Sci 5 (3). DOI: 10.5614/j.eng.technol.sci.2020.52.3.7

Newing H. 2010. Conducting research in conservation: Social science methods and practice. Routledge.

Nugraha S, Sumardi S. 2019. Destinasi wisata kuliner berbasis makanan tradisional di Kabupaten Toba Samosir. Jurnal Akademi Pariwisata Medan 7 (2): 33-46. DOI: 10.36983/japm.v7i2.51

Nurlaeni Y, Junaedi DI. 2018. Studi ekologi habitat, teknik perbanyakan dan pengoleksian dalam rangka konservasi ex-situ andaliman $\begin{array}{lllll}\text { (Zanthoxyllum acanthopodium } & \text { DC.). Bioma } 14 & \text { (2): 79-88. }\end{array}$ [Indonesian]

Parhusip AJ, Jenie BSL, Rahayu WP, Yasni S. 2010. Effect of andaliman (Zanthoxylum acanthopodium DC) extracts upon permeability and hydrophobicity of Bacillus cereus. Jurnal Teknologi dan Industri Pangan 16 (1), 24. [Indonesian]

Phoulivong S, McKenzie EHC, Hyde KD. 2012. Cross infection of Colletotrichum species; a case study with tropical fruits. Curr Res Environ Appl Mycol 2 (2): 99-111. DOI: 10.5943/cream/2/2/2
Purba ST, Sinaga DP. 2017. Evaluasi potensi ekstrak tumbuhan andaliman (Zanthoxylum acanthopodium) sebagai potensi imunostimulan pada tikus (Rattus norvegicus L.). Universitas Negeri Medan, Indonesia. [Indonesian]

Raja RNL, Hartana A. 2017. Variasi morfologi andaliman (Zanthoxylum acanthopodium) di Sumatra Utara. Floribunda, 5 (7): 258-266. DOI: 10.32556/floribunda.v5i7.2017.143

Reijintyes C, Haverkort B, Waters-Bayer A. 1992. Farming for The Future: An Introduction to Low-External Input and Sustainable Agriculture. Leusden, Ilia, NL.

Sangha KK, Jalota RK, Midmore DJ. 2006. Litter production, decomposition and nutrient release in cleared and uncleared pasture systems of central Queensland, Australia. J Trop Ecol 22 (2): 177189.

Satria D. 2020. Aktivitas antikanker dan antioksidan fraksi etilasetat buah andaliman (Zanthoxylum acanthopodium DC.) dan herba poguntano (Picria fel-terrae Lour.). [Indonesian]

Siahaan L. 2018. Pola penyebaran spasial dan kelimpahan andaliman (Zanthoxylum acanthopodium DC.) di Pulau Samosir, Sumatera Utara. Repository Universitas HKBP Nommensen, Indonesia. [Indonesian]

Siahaan L, Hilwan I, Setiawan Y. 2019. Spatial distribution of andaliman potential habitat (Zanthoxylum acanthopodium DC.) in Samosir Island, North Sumatera. Journal of Natural Resources and $\begin{array}{llll}\text { Environmental Management } 9 & \text { (4): 61-71. DOI: }\end{array}$ 10.29244/jps1.9.4.861-871

Siahaan R. 2000. Kajian Mutu Dengke Na Niura dengan Pemberian Konsentrasi Andaliman dan Ekstrak Jahe yang Bervariasi. [Skripsi]. Unika St. Thomas, Medan. [Indonesian]

Sibero MT, Siswanto AP, Murwani R, Frederick EH, Wijaya AP, Syafitri E, Farabi K, Saito S, Igarashi Y. 2020. Antibacterial, cytotoxicity and metabolite profiling of crude methanolic extract from andaliman (Zanthoxylum acanthopodium) fruit. Biodiversitas 21(9) 4147-4154. DOI: 10.13057/biodiv/d210928

Simbolon BR, Panjaitan DTMR. 2020. Komunikasi pemberdayaan terhadap peningkatan daya saing ekonomi bangsa berwawasan gender pada petani andaliman di Samosir. Talenta Conference Series: Local Wisdom, Social, and Arts (LWSA). [Indonesian]

Simbolon WI, Kardhinata EH, Bangun MK, Simatupang S. 2018. Identifikasi Karakter Morfologis Andaliman (Zanthoxylum acanthopodium DC.) di beberapa kabupaten di Sumatera Utara. Jurnal Online Agroekoteknologi 6 (4): 745-756. [Indonesian]

Simorangkir A. 2019. Analisis preferensi konsumen terhadap andaliman (Zanthoxylum acanthopodium DC.)(Kasus: konsumen pada beberapa pasar outlet andaliman di Kota Medan). [Indonesian]

Sinaga RE, Prasetyo HA. 2020. Analisis kadar minyak atsiri andaliman Desa Bandar Huta Usang Kabupaten Dairi (Zanthoxylum acantophodium D.). Seminar Nasional Teknologi Komputer \& Sains (SAINTEKS) 1 (1): 655-657.

Siregar BL, Siregar LAM, Nisa TC, Putri LAP. 2019. Flower morphology and inflorescence of Andaliman (Zanthoxylum acanthopodium DC.) from Dairi, North Sumatera. IOP Conference Series: Earth and Environmental Science. DOI: 10.1088/1755-1315/260/1/012178

Siregar BL. 2013. Perkecambahan dan pematahan dormansi benih andaliman (Zanthoxylum acanthopodium DC.). Indones J Agron 41 (3). DOI: 10.24831/jai.v41i3.8106 [Indonesian]

Sitanggang FMC, Duniaji AS, Pratiwi IDPK. 2019. Daya hambat ekstrak buah andaliman (Zanthoxylum acanthopodium DC) dalam etil asetat terhadap pertumbuhan Escherichia coli. Jurnal Ilmu Dan Teknologi Pangan (ITEPA) 8 (3): 57-66. DOI: 10.24843/itepa.2019.v08.i03.p04 [Indonesian]

Sudalmi ES. 2012. Pembangunan pertanian berkelanjutan. INNOFARM: Jurnal Inovasi Pertanian 9(2). [Indonesian]

Suriani C, Prasetya E, Harsono T, Handayani D. 2019. Habitat characteristics of Andaliman (Zanthoxylum acanthopodium DC) in North Sumatra using a GIS (Geographical Information System) approach. J Phys: Conf Series 1317 (1): 012097. DOI: 10.1088/17426596/1317/1/012097

Susanti N, Situmorang E, Fitri W. 2020. Effectiveness of the antibacterial activity of n-hexane andaliman (Zanthoxylum Acanthopodium DC) extract against Bacillus subtilis, Salmonella typhi, and Staphylococcus aureus. J Phys: Conf Ser 1462 (1). DOI: 10.1088/1742$6596 / 1462 / 1 / 012072$

Tjahjandarie T, Irza GAN, Saputri RD, Tanjung M. 2019. Senyawa senyawa alkaloid furokuinolin dari kulit batang Zanthoxylum 
acanthopodium DC. Jurnal Sains dan Kesehatan 2 (2): 89-62. DOI: 10.25026/jsk.v2i2.121 [Indonesian]

Tjitrosemito S, Guhardja E, Qayim I, Leuschner C. 2011. Litterfall production and leaf-litter decomposition at natural forest and cacao agroforestry in Central Sulawesi, Indonesia. Asian J Biol Sci 4 (3): 221-234. DOI: 10.3923/ajbs.2011.221.234

Tripathi OP, Tripathi RS. 2009. Litter production, decomposition and physicochemical properties of soil in 3 developed agroforestry systems of Meghalaya, Northeast India. Afr J Plant Sci 3 (8): 160167.

Wijaya CH. 1999. Andaliman, rempah tradisional Sumatera Utara dengan aktivitas antioksidan dan antimikroba.

Wijaya CH, Hadiprodjo IT, Apriyantono A. 2002. Identification of volatile compounds and key aroma compounds of andaliman fruit
(Zanthoxylum acanthopodium DC.). Food Sci Biotechnol 2 (6): 680683.

Wijaya CH, Napitupulu FI, Karnady V, Indariani S. 2019. A review of the bioactivity and flavor properties of the exotic spice "andaliman" (Zanthoxylum acanthopodium DC.). Food Rev IntL 35 (1): 1-9. DOI: 10.1080/87559129.2018.1438470

Worotikan RV, Tuju EA, Kawuwung F. 2018. Analisis efektivitas antidiabetes ekstrak etanol buah andaliman (Zanthoxylum acanthopodium DC) pada histopatologi ginjal tikus putih (Rattus novergicus) yang diinduksi alloksan. JSME (Jurnal Sains, Matematika \& Edukasi) 5 (1): 29-37. [Indonesian]

Wowor AE, Thomas A, Rombang JA. 2020. Kandungan unsur hara pada serasah daun segar pohon (mahoni, nantu dan matoa). EUGENIA 25 (1). DOI: 10.35791/eug.25.1.2019.31395 [Indonesian] 